TUGAS FILSAFAT MORAL

\title{
ANALISIS KASUS YANG TERJADI DALAM KEHDUPAN SEHARI-HARI DI
} INDONESIA

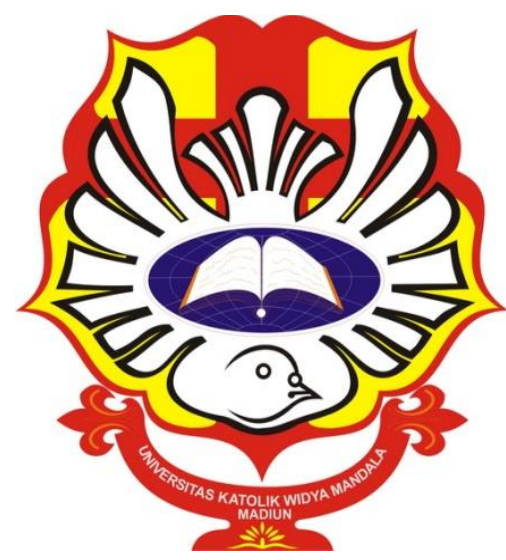

Disusun Oleh:

Oki Candra Woro Kuswanto

NIM 41418007

FAKULTAS TEHNIK

JURUSAN TEHNIK INDUSTRI

UNIVERSITAS KATOLIK WIDYA MANDALA MADIUN

MADIUN 2018 


\begin{abstract}
Abstrak
Dalam kasus ini, saya akan membahas tentang Kasus Korupsi 41 Anggota DPRD Malang Hingga PAW Massal. Kasus tersebut mengenai suap dan grativikasi yang melibatkan 41 anggota dari 45 anggota DPRD kota Malang.

Dari kasus di atas kita dapat mengetahui bahwa seorangpemimpin yang sangat tidak bermoral. Dimana menggunakan kekuasaan jabatannya untuk kepentingan pribadi dari pada kepentingan bersama yaitu kepentingan rakyat. Dia memperkaya diri sendiri dengan cara yang tidak semestinya dan melanggar hukum

Sungguh sangat disayangkan, seorang pemimpin yang seharusnya menjadi ujung tombak rakyat nya malah menyelewengkan amanat tersebut. Begitulah yang terjadi jika seorang pemimpin tidak mengerti dan mengetahui apa itu kehidupan yang bermoral.
\end{abstract}




\section{A. Perjalanan Kasus Korupsi 41 Anggota DPRD Malang Hingga PAW Massal}

Sumber :

https://news.detik.com/berita/4206487/perjalanan-kasus-korupsi-41-anggota-dprdmalang-hingga-paw-massal

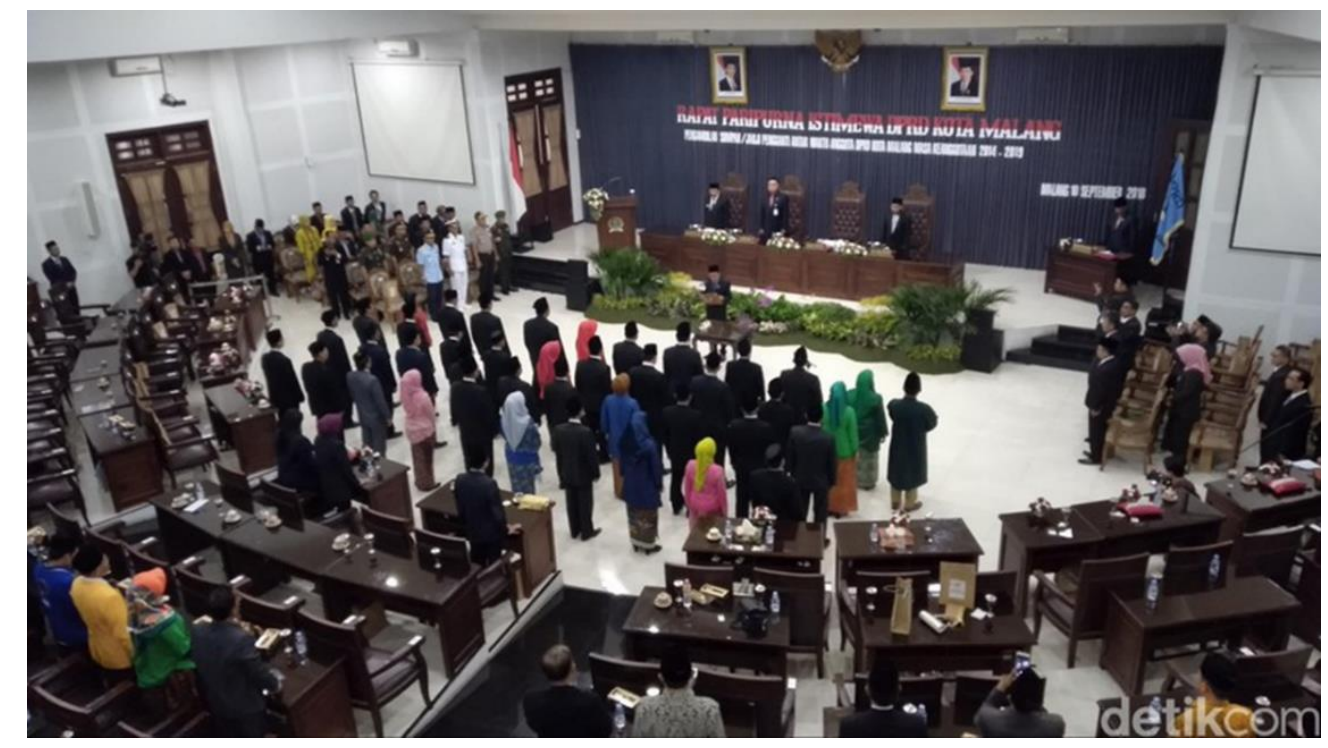

Jakarta - KPK telah menetapkan 41 anggota DPRD Kota Malang sebagai tesangka kasus dugaan suap dari Wali Kota nonaktif Moch Anton. Kini, para anggota DPRD yang menjadi tersangka korupsi massal itu telah diganti seluruhnya.

Kasus ini sendiri terdiri dari 3 tahap. Pada tahap pertama di tahun 2017, KPK menetapkan 2 orang tersangka, yaitu Ketua DPRD Malang saat itu, M Arief Wicaksono dan Kadis PUPPB Malang saat itu, Jarot Edy Sulistiyono.

Arief kini telah divonis 5 tahun penjara dan denda Rp 200 juta subsider 2 bulan kurungan serta pencabutan hak politik selama 2 tahun. Sementara, Jarot divonis bersalah dan dijatuhi hukuman 2 tahun 8 bulan penjara dan denda Rp 100 juta subsider 3 bulan penjara.

Setelah itu, pada bulan Maret 2018, KPK menetapkan 19 orang tersangka. Mereka ialah Wali Kota Malang nonaktif, Moch Anton bersama 18 anggota DPRD Kota Malang. Kini ke-19 orang tersebut sedang diproses di pengadilan. 
Pada tahap ketiga di bulan September 2018, ada 22 anggota DPRD Malang yang ditetapkan KPK sebagai tersangka suap dan gratifikasi. Mereka diduga menerima duit suap Rp 12,5-50 juta dari Anton terkait pengesahan Rancangan Perda tentang Perubahan APBD 2015. '

Para anggota DPRD Kota Malang itu juga diduga menerima gratifikasi senilai total Rp 5,8 miliar. Duit itu diduga terkait dana pengelolaan sampah di Kota Malang.

Akibat kasus itu, hanya tersisa 5 (ada 1 anggota DPRD yang merupakan hasil PAW dari salah satu tersangka) dari total 45 anggota DPRD Malang. Partai politik yang memiliki wakilnya di DPRD Malang menjadi tersangka pun segera melakukan pergantian antarwaktu (PAW) secara massal.

Pada Senin (10/9/2018) para anggota hasil PAW itu dilantik oleh Gubernur Jawa Timur, Soekarwo dalam sidang paripurna istimewa DPRD Kota Malang. Pelantikan juga dihadiri oleh Menteri Dalam Negeri Tjahjo Kumolo.

"Menindaklanjuti surat keputusan gubernur, 40 anggota DPRD pengganti diresmikan dan dilantik hari ini," kata Wakil Ketua DPRD Abdulrachman di meja pimpinan rapat paripurna istimewa di Gedung DPRD Kota Malang Jalan Tugu, Senin $(10 / 9 / 2018)$.

Berikut nama-nama anggota DPRD Kota Malang dipilih dan dilantik melalui PAW:

\section{PDIP}

1. Retno Mastuti

2. Heri Suyanto

3. Bambang Heri Susanto

4. Luluk Zuhriyah

5. Sutikno

6. Rusman Hadi 
7. Sugiono

8. Edy Hermanto

9. Yusana Intiyaswati

\section{PKB}

1. Abdul Wahid

2. Ike Kisnawati

3. Siti Aminah

4. M Taufik

5. Siswo Waroso

\section{Partai Golkar}

1. Musolli

2. Retno Sumarah

3. Arief Budiarso

4. Budianto

5. Eddy Widjarnako

\section{Partai Demokrat}

1. Nawang Nugraning Wedhi

2. Sulastri

3. Nanik Qurrata Akyunin

4. Arif Darmawan

5. Fransiska Rahayu

\section{Partai Gerindra}

1. Dharman Susanto

2. Moch Andi Mochsoni

3. Andri Wiwanto

4. Moch Ula

\section{PAN}

1. Lookh Makhfud

2. Dito Arief Nurakhmadi 
3. Ferry Adha Adianto

\section{PKS}

1. Helmi Teguh Yuwana

2. Syaiful Ali Fatah

3. Masduki

\section{PPP}

1. Abdul Rozaq

2. Achmad Subandiri

3. Joko Supriyono

\section{Partai Hanura}

1. Nirma Chris Nindya

2. Purwono Tjokro Darsono

3. Nicolia Mundzir

\section{Partai NasDem}

1. Didik Suprayitno.

\section{B. HUBUNGAN HUKUM DAN MORAL}

Hubungannya dapat dimengerti dalam skema hubungan antara hukum kodrat dan hukum positif yaitu, moral haruslah meresapi hukum. Moral itu pertama-tama soal baik buruk (soal nilai-nilai normatif). Hukum adalah soal perintah dan larangan. Hukum bukan soal nasihat, tapi soal perintah dan larangan, karena kalua tidak menjalankan perintah atau melanggar larangan akan dihukum.

Hukum haruslah tunduk pada moral. Artinya, apa yang diperintahkan haruslah merupakan kebaikan; dan apa yang dilarang haruslah merupakan keburukan. Bkan sebaliknya, dilarang maka buruk; diperintah maka baik! Jika moral dipahami sebagai demikian (dilarang maka buruk, diperintah maka baik), maka moral tersebut sangat legalistis; dana pa hukum dipahami seperti itu, akan terjadi kemungkinan manipulasi positivism hukum yang sangat hebat. 


\section{NILAI MORAL}

Dapatkah kita membutakan diri terhadap aneka kekerasan dan ketidak adilan yang nyata dalam masyarakat dan memandangnya melulu sebagai peristiwa tanpa nilai? Sebut misalnya, seorang pengemudi becak yang terpaksa menggantung diri karena dilarang membecak, padahal becak baru 1 minggu yang lalu dibeli dengan kredit yang berbunga 50\% perbulan. Dapatkah kita berkata bahwa itu hanya sebuah peristiwa tanpa ada nilai-nilai yang menyertai dan berpartisipasi dalam peristiwa itu? Atau, seorang nenk renta yang mencari makan untuk menyambung hidupnya dengan mencuri daun pisang di tanah milik tetangga dibunuh oleh pemilik tanah karena kesal dan jengkel terhadap berbuatan mencuri dari si nenek. Dapatkah kita melihat peristiwa kematian; dari sang nenek rentak tersebut hanya sebagai suatu fenomen biasa tanpa nilai, misalnya nilai keadilan yang dirampas pemilik tanah dari hidup sang nenek?

Manusia sejauh memliki kesadaran dalam tindakannya, dia selalu mengajukan nilai-nilai. Jadi diskusi mengenai nilai moral harus langsung diandaikan sejauh manusia ada, hidup, bertindak. Kesadaran dan kehidupan manusia adalah bukti yang secara fenomenal mengatakan tampilannya nilai-nilai. Mengenai benarnya eksistensi nilai sejauh manusia sadar, kita barang kali bisa membandingkanya dengan revolusi filsafat Descartes. Jika dalam Descartes cogito ergo sum(saya berfikir atas sadar) maka saya mengajukan nilai-nilai.

Aktifitas penilaian ini menjadi ciri khas manusia. Kesadaran paling langsung dan serentak mengenai nilai jelas dalam kenyataan bahwa kita' "menilai", diri sendiri dan orang lain. "menilai'" diri sendiri artinya kita melakukan paling sedikit kesadaran akan segala apa yang kita lakukan, rasakan, pikirkan, olah dan seterusnya. Kesadaran semacam ini jelas memproduksi nilai-nilai atau sangat mengandaikan paham nilai-nilai.

Nilai moral bukan opsional, melainkan wajib. Dihadapan nilai, kita tidak mungkin bersikap ya atau tidak. Nilai moral adalah fenomen kewajiban. Kesaksian tentang kewajiban ada dalam tindakan dan Bahasa manusia sehari-hari. Kewajiban manusia hadir dalam tindakan dan Bahasa bukan berfikir. Bahasa melukiskan, mengungkapkan, memberikan wacana(referensi) atau semacamnya berkaitan fenomen kewajiban. Tindakan mewujudkan kewajibannya. Dengan 
tindakan, dimaksudkan dalam artian luas, bukan hanya sekedar tindakan fisik melainkan juga segala apa yang merepukan pencetusan eksistensi manusiawi kita. Konfirmatif mengenai karakter normative etika ada dalam keseharian hidup manusia. Karakter normatif etika dibuktikan dalam fenomen peristiwa-peristiwa kehidupan kongkret.

Prinsip bonum faciendum et malum vitandum (kebaikan dilakukan dan keburukan harus dihindarkan) adalah penegas realitas bahwa hidup manusia langsung menyentuh kewajiban moral. Mengapa kebaikan harus atau wajib dilakukan dan keburukan harus atau wajib di cegah? "Harus' artinya wajib, mutlak, tidak boleh tidak, punya daya ikat. Mengapa 'baik' itu punya daya ikat untuk dilakukan? Bagi Kant, karena itulah kodrat kebaikan. Kodrat baik itu sekaligus mencetus ' 'harus', Bagi Aristoteles, kebaikan harus dilakukan karena menjanjikan kebahagian. Etika kebaikan Aristotelian bersifat teleologis, yaitu menuju kepada kebahagian. Dengan demikian, kebahagian jelas merupakan itu yang tidak dating dengan sendirinya, tidak begitu saja diraih. Kebahagiaan adalah itu yang harus dikejar, diperjuangkan, diraih. Jika dalam Aristoteles, keharusan untuk menjalankan kebaikan menemukan alasan pada tujuan kebahagiaan, dalam Kantkeharussaannya terletak pada kodrat kebaikan itu sendiri. 


\section{KESIMPULAN}

Sesuai dengan kasus Korupsi 41 Anggota DPRD Malang Hingga PAW Massal dan hubungan hukum dengan moral serta nilai moral dapat menarik kesimpulan.

Dari kasus ini dapat dilihat bahwa pelaku yang seorang anggota DPRD tidak mencerminkan seorang yang bermoral. Bisa dilihat dari tindakan mereka, yaitu melakukan suap dan grativikasi secara bersama-sama. Padahal seorang pemimpin harusnya bertindak selayaknya pemimpin. Serta mengayomi, melayani dan menjaga masyarakat.

Dalam hal ini telah melanggar beberapa sila PANCASILA yaitu sila pertama 'Ketuhanan Yang Maha Esa'. Sebelum para tersangka dilantik menjadi anggota DPRD, mereka telah di sumpah dahulu dengan kitab suci. Tetapi mereka dengan mudah nya dan secara bersama-sama melanggar sumpah tersebut. Dalam artian mereka tidak menanamkan nilai moral beragam dalam kehidupan mereka.

Sila ke-empat 'Kerakyatan Yang Dipimpin Oleh Hikmat Kebijaksanaan Dalam Permusyawaratan Perwakilan'. Sebagai wakil rakyat yang baik dan bermoral, seharusnya tidak melakukan tindakan yang tidak baik seperti yang dilakukan para anggota DPRD tersebut. Mereka memimpin dengan sangat tidak bijaksana malah menyelewengkan kekuasaan merekan untuk kepentingan pribadi.

Dari kasus di atas yang sudah saya analisis, dapat diambil hikmah dan pembelajaran secara bersama-sama bagi kita semua sebagai warga negara Indonesia. Hendaknya kita sebagai warga negara Indonesia menjujung tinggi nilai-nilai MORAL, dengan cara menerapkannya pada kehidupan sehari-hari yang kita jalani. Sebab MORAL dan PANCASILA adalah pedoman kehidupan Bangsa Indonesia. Agar terciptanya kedamaian, kedilan, kesejahteraan bagi seluruh Rakyat Indonesia 


\section{DAFTAR PUSTAKA}

://news.detik.com/berita/4206487/perjalanan-kasus-korupsi-41-anggotadprd- -hingga-paw-massal

(Diakses tanggal 17 November 2018)

Dewantara, Agustinus. "Filsafat Moral (Pergumulan Etis Keseharian Hidup Manusia)." (2017).

Dewantara, Agustinus. "Alangkah Hebatnya Negara Gotong Royong (Indonesia dalam Kacamata Soekarno)." (2017).

Dewantara, A. W. (2015). PANCASILA SEBAGAI PONDASI PENDIDIKAN AGAMA DI INDONESIA. CIVIS, 5(1/Januari). 